This item was submitted to Loughborough's Research Repository by the author.

Items in Figshare are protected by copyright, with all rights reserved, unless otherwise indicated.

\title{
Polyphonic legality: power of attorney through dialogic interaction
}

\section{PLEASE CITE THE PUBLISHED VERSION}

https://doi.org/10.1177/0964663918803409

\section{PUBLISHER}

SAGE Publications (๑ The Authors)

\section{VERSION}

AM (Accepted Manuscript)

\section{PUBLISHER STATEMENT}

This work is made available according to the conditions of the Creative Commons Attribution-NonCommercialNoDerivatives 4.0 International (CC BY-NC-ND 4.0) licence. Full details of this licence are available at: https://creativecommons.org/licenses/by-nc-nd/4.0/

\section{LICENCE}

CC BY-NC-ND 4.0

\section{REPOSITORY RECORD}

Harding, Rosie, and Elizabeth Peel. 2019. "Polyphonic Legality: Power of Attorney Through Dialogic Interaction". figshare. https://hdl.handle.net/2134/34865. 
Rosie Harding \& Elizabeth Peel (forthcoming, 2018) 'Polyphonic Legality: Power of Attorney through Dialogic Interaction' Social \& Legal Studies.

Author's Post Print. Accepted for Publication in Social \& Legal Studies on 6 September 2018. Please cite published version where possible.

\section{Polyphonic Legality: Power of Attorney through Dialogic Interaction}

Rosie Harding ${ }^{1}$ and Elizabeth Peel ${ }^{2}$

\section{Abstract}

Building on Bakhtin's work on discourse, this paper uses the concept of polyphony to explore capacity law praxis. Drawing on everyday interaction about power of attorney, we demonstrate how legal, lay, and medical understandings of capacity operate dialogically, with each voice offering distinct expressions of legality. Analysing lay and medical interactions about Lasting Power of Attorney - the legal authority to make decisions on behalf of a person who loses the mental capacity to make their own decisions - we argue power of attorney holds a 'polyphonic legality'. We argue that legal concepts (like power of attorney) are constructed not solely through official law, but through dialogic interaction in their discursive fields. We suggest 'polyphonic legality' offers an innovative approach to understanding how law works in everyday life, which is attentive to the rich texture of legality created by and through the multiple voices and domains of socio-legal regulation.

Keywords: Capacity Law; Conversation Analysis; Dementia; Law in Action; Polyphony; Power of Attorney

This paper explores the ways that discourse around Lasting Power of Attorney (LPA) under the Mental Capacity Act 2005 (MCA) interacts with the formal legal framework to explore the everyday praxis of capacity law. Power of attorney is a mechanism by which people who anticipate losing cognitive ability (the donor) can nominate a third party (the attorney or donee) to make legally binding decisions on their behalf. Decisions made and actions taken by an attorney are considered in law to be undertaken by the donor. In English law, two types of LPA are available, covering either personal welfare issues or property and affairs. 'Multiple attorneys can be appointed, to act either jointly or severally, and different attorneys can be appointed to each 'type' of LPA. A donor can grant specific or wide powers to the donee, within the formal constraints of the law. At the end of March 2017, there were 2,478,758 current Power of Attorney documents on the register held by the Office of the Public Guardian (OPG, 2017: 12). Despite being such a commonplace legal tool, the concept and practice of power of attorney has received surprisingly little attention from socio-legal scholars. A small literature exists that discusses elements of the legal context and content of power of

\footnotetext{
${ }^{1}$ Professor of Law and Society, Birmingham Law School, University of Birmingham, UK. Email: r.j.harding@bham.ac.uk (corresponding author)

${ }_{2}^{2}$ Professor of Communication and Social Interaction, School of Social Sciences, Loughborough University, UK. Email e.peel@lboro.ac.uk.
} 
Author's Post Print. Accepted for Publication in Socio-Legal Studies on 6 September 2018. Please cite published version where possible.

attorney (e.g. Dalley et al, 2017; Samanta, 2009; 2012), but most of the legal literature on this topic is doctrinally or practice oriented (e.g. Rich, 2015; Edwards, 2016).

We provide a critical interrogation of the socio-legal milieu of power of attorney, which we understand as a mechanism to ensure the right to enjoy legal capacity for persons with impaired mental capacity (Harding, 2015). This paper offers analysis of naturalistic interaction about getting and granting LPAs in three different settings: a focus group, an informal lunch, and in two memory clinic appointments. Through this analysis, we build on the concept of polyphony (Bakhtin, 1984) to offer a reading of the multiple voices that combine to create the socio-legal totality of power of attorney. We show how different constructions of power of attorney are present in these settings, and also how these formulations do not always align with the statutory frameworks that guide the granting, and using, of powers of attorney.

To facilitate the reading of these multiple voices, we offer a new conceptual frame for socio-legal studies, 'polyphonic legality', as a tool for exploring the myriad strands of engagement, construction and interpretation that mesh together to create the everyday praxis of legal concepts. In suggesting that the concept of polyphony has explanatory purchase in socio-legal theory, we seek to build on the foundations provided by the rich seam of socio-legal work that stems from constitutive approaches to law (Fleurry-Steiner \& Neilsen, 2006; McCann, 1992). These socio-legal approaches seek to explore how and why law is understood, mobilised and resisted in everyday life. A major strand of this constitutive scholarship has used the frame of legal consciousness studies (e.g., Cowan, 2004; Ewick \& Silbey, 1998; Harding, 2011), an approach to understanding how law works in everyday life which also seeks to interrogate legal hegemony and expose the enduring power of official law (e.g., Sarat, 1990; Silbey, 2005). Our understanding of polyphonic legality engages with, and develops, these constitutive approaches to law. But rather than focus on what everyday engagement with law means for formal legal frameworks, we seek to expose the multiple strands of legality that combine to create the everyday experience of regulatory frameworks. Polyphonic legality is also attentive to the plurality of norms that shape the experience of law outside formal legal institutions. It therefore contributes to critical pluralist accounts of law which seek break down the boundaries between formal law and other normative frameworks which shape and guide social action (e.g., Davies, 2017).

We begin by setting out how we use the concept of 'polyphony' to cast light on the content and meaning of everyday talk about power of attorney. We then provide an argument for the importance of interrogating 'polyphonic legality' to gain a greater understanding of the complex ways that law works in everyday life. Next, we outline the contexts in which the data we analyse 
Author's Post Print. Accepted for Publication in Socio-Legal Studies on 6 September 2018. Please cite published version where possible.

were collected, and the challenges and advantages of analysing naturally occurring talk. In the third part of the paper, we analyse the talk itself, exposing the content and form of discourses of power of attorney, demonstrating how the polyphonic legality of power of attorney is generated. We conclude with a discussion of the implications of polyphonic legality in mental capacity law and socio-legal studies.

\section{Polyphonic Legality}

In the analysis that follows, we seek to demonstrate that power of attorney holds a 'polyphonic legality', by which we mean that power of attorney is constructed not by the rules set out in official law, but through the interplay of distinct voices, operating in a dialogic manner. The voices that we focus on in our analysis of power of attorney are found in lay and medical interactional contexts. We argue that the different ways power of attorney is constructed by these voices weave together to create the polyphonic legality of power of attorney. Polyphonic legality, as we understand it, has a discursive and constructionist epistemology. In suggesting it as a tool for socio-legal studies, we explicitly seek to expose how dialogue - the discussion, description and explanation of legal concepts in everyday praxis - shapes the meaning of those concepts. In this section, we set out our understanding of polyphony, before exploring what polyphonic legality adds to constitutive approaches to socio-legal studies.

\section{The Concept of Polyphony}

Bakhtin (1984) used the concept of polyphony in his analysis of Dostoevsky's poetics. He argued that:

Dostoevsky...creates ... A plurality of independent and unmerged voices and consciousnesses, a genuine polyphony of fully valid voices... a plurality of consciousnesses, with equal rights and each with its own world, combine but are not merged in the continuity of the event (Bakhtin, 1984:6. Original emphasis).

A key component of Dostoevsky's polyphonic novel, according to Bakhtin, is that it is 'dialogic'. By this, he means that 'it is constructed not as the whole of single consciousness, absorbing other consciousnesses as objects into itself, but as a whole formed by the interaction of several consciousnesses, none of which entirely becomes an object for the other' (Bakhtin, 1984:18). Polyphony, following Bakhtin, requires us to think of the product of different voices as retaining those voices within it. Rather than each 'consciousness' fusing together into a new whole, and therefore erasing the individual constitutive voices, polyphony retains the distinct voices that come together to create it. 
Author's Post Print. Accepted for Publication in Socio-Legal Studies on 6 September 2018. Please cite published version where possible.

This analysis can be borrowed by socio-legal scholars to help us to understand the ways that legal concepts or tools develop and change through everyday dialogic interaction about them. We use power of attorney as an example of this polyphonic legality. In the analysis that follows, we show how power of attorney derives not solely from its doctrinal legal underpinnings, but rather is constructed through dialogue between and within the different registers of everyday interaction, medical interaction and legal rules. In asserting the polyphonic legality of power of attorney, we seek to demonstrate that the formal legal construction of power of attorney is one voice in many. Further, following Bakhtin, and this is key to unlocking the novelty of polyphonic legality for sociolegal studies, we argue that this 'official' legal voice has no more importance in 'power of attorney' than the other voices that make up its polyphonic legality.

An alternative metaphor to unpack this idea of polyphonic legality is the difference between monophonic, homophonic and polyphonic music. Monophonic music has only one melodic voice (e.g. a simple folk tune played by a solo instrument). Homophonic music has a single melodic line, supported by a chordal or harmonic accompaniment. Homophonic music is marked by having a clearly discernible melody that takes predominance (e.g. much western popular and classical music). Polyphonic music, however, does not have a single melodic line. Instead, the melodic shape of the music is created through counterpoint, the interaction of several melodic lines. Perhaps the bestknown examples of polyphonic music are JS Bach's keyboard works, which offer excellent examples of the interplay of melodic lines that typifies the use of counterpoint in musical polyphony.

Each of these musical terms point to different ways of understanding law and legal concepts. An example of monophonic legality might be found in the declaratory theory of the common law, the 'fairy-tale' wherein judges were presumed to "discover and declare the law which is throughout the same." "ii Homophony in law, on the other hand, may be argued to reflect dominant understandings of the interaction between legislation and statutory interpretation, or the development of the common law. Here, the legal rule is predominant, it acts as the melodic line, but full content of that rule is ascertained through legislative, adversarial and/or judicial discourse. The meanings and textures of the legal rule are expanded, developed and made whole by the accompaniment of judicial and interpretive discourse. Polyphonic legality, we argue, is a different form of legal idea, where legality is constructed through the interaction of discourse from different socio-legal domains.

\section{Polyphonic Legality, Constitutive and Pluralist Approaches to Law}

As discussed above, we find the concept of polyphony useful as a tool for exploring the richly textured legality that is created through dialogic interaction within and between different discursive 
Author's Post Print. Accepted for Publication in Socio-Legal Studies on 6 September 2018. Please cite published version where possible.

fields. The idea that we should look beyond, or de-centre, official law is not new to socio-legal studies. Our argument about the importance of exploring polyphonic legality therefore owes a debt to many previous socio-legal approaches to understanding the place of, engagement with, and avoidance of, law in everyday life (Cowan, 2004; Ewick and Silbey, 1998; Merry, 1990; Sarat, 1990). It also sits alongside critical engagements with legal pluralism (Davies, 2017; Merry 1988) in exploring the interaction of different regulatory frames. In this section, we trace the ways that this rich seam of socio-legal scholarship supports and influences our understanding of polyphonic legality.

In common with legal consciousness studies (Ewick and Silbey, 1998), polyphonic legality looks to explore the place of law in everyday life. Instead of focusing on arguments about the enduring power of law (Silbey, 2005), or exploring how broad schemas of legal consciousness (like Ewick and Silbey's [1998] powerful 'before', 'with' and 'against' the law narratives) help to explain legal culture, polyphonic legality has a different orientation. We contend that some ostensibly doctrinal legal concepts (here, power of attorney) can only be fully understood by exploring the multi-textured whole that is created when the different strands of their polyvocality are brought together. In other words, instead of looking to everyday life to find meaning of and for official law, we use polyphonic legality to offer a rich, nuanced and textured reading of how legal ideas and concepts (like power of attorney) are socially and discursively constructed.

Polyphonic legality is an explicitly plural concept. In suggesting it as a tool for socio-legal studies we emphasise, like other critical scholarship in legal pluralism (e.g., Davies, 2017; Harding, 2011), the multiple, interwoven norms and normativities (legal, social, interactional) that shape everyday talk and action. Like Davies (2017), we are interested in the ways that different, related things and ideas coexist in a comparative space, and in relation to each other. The doctrinal concept of power of attorney, as we will show, coexists and interacts with lay understandings of it, and medical professional uses of it to create a polyphonic legality. In offering polyphonic legality as a plural concept, we are not, to be clear, suggesting that there is formal law and things that are not formal law that operate as a distinct normative or regulatory regime (like customary law in the anthropological tradition of legal pluralism). Instead, our polyphonic approach to legality necessitates an ongoing de-centring of formal law, and an acknowledgement of the equal importance of the other voices that combine with it to create the polyphonic legality of a legal concept or idea.

Our polyphonic approach also has much in common with the ideas at the heart of Ehrlich's (1936) account of 'living law' (see further Nelken, 2008; Hertogh, 2009). Through our concept of polyphonic legality, we seek to encourage a methodology for socio-legal studies that draws on naturalistic data. 
Author's Post Print. Accepted for Publication in Socio-Legal Studies on 6 September 2018. Please cite published version where possible.

Like Ehrlich, we are interested in looking at "direct observation of life, of commerce, of customs and usages, and of all associations" (Ehrlich, 1936/2002: 493) as well as the official law as it is expressed in doctrine. As we discuss further below, the methodological approach we take is key to our understanding of polyphonic legality. By exploring the discursive, dialogic and interactional constructions of power of attorney in lay and medical discourse, we demonstrate how different strands of legal, lay and medical interaction weave together to generate the polyphonic legality of power of attorney.

In building from these diverse socio-legal literatures and insights, the idea of polyphonic legality has novel analytic potential that differentiates it from these literatures, providing a fresh set of conceptual tools for socio-legal studies. In addition to this conceptual novelty, we use tools from ethnomethodology, an uncommonly used approach in socio-legal research, iii but one which has a great deal of relevance for constitutive theoretical approaches to law and society.

\section{Observing Polyphonic Legality: Ethnomethodology and Conversation}

\section{Analysis}

In offering polyphonic legality as a conceptual tool, we seek to draw insights from ethnomethodology and conversation analysis (see Sidnell, 2010 for an introduction) into socio-legal studies. Ethnomethodology is an approach, founded in the work of Garfinkel (1967), that seeks to explore and explicate social action from the 'bottom up'. It seeks to understand the methods people use to produce their world, through their actions and interactions. In ethnomethodology, everyday interaction is understood to create the 'social fact' (Durkheim, 1982) of a particular phenomenon. Ethnomethodological approaches look at both the account of a social fact, and the methods used to create that account through language and shared meaning. Despite some attempts to persuade socio-legal researchers to take up this approach in order to offer thick descriptions of legal behaviours, actions and spaces (Travers, 1997; Travers and Manzo, 1997), ethnomethodology has yet to gain significant purchase within socio-legal studies. Socio-legal resistance to ethnomethodological approaches may, at least in part, be attributable to the relative absence of methodological tools within the canon of law and society research that utilise naturalistic data to analyse social interaction as it happens, rather than as it is explained or reported (such as is generated through qualitative interview research).

Since the 1960s, the preeminent approach for analysing social interaction has been conversation analysis (CA). CA focuses on the detail of the interaction as it unfolds, and as Antaki (2011: 2) summarises "provides a detailed, coherent, integrated catalogue of normative sequences of language in interaction" and the actions these produce. In this 'pure' CA there is an emphasis on not 
Author's Post Print. Accepted for Publication in Socio-Legal Studies on 6 September 2018. Please cite published version where possible.

making any assumptions about the data and engaging in 'unmotivated looking'. Criticisms of this form of CA include it being 'apolitical' (Stokoe, 2011). The tools of CA can, however, be applied not only to understand interaction, but to identify where and how it might be changed (Antaki, 2011), which enables scope for more critical interpretation of practice in a wide variety of settings. Some proponents have further demonstrated that CA can be used for expressly political, feminist, research (e.g., Kitzinger, 2000). Whilst CA is certainly a 'micro' approach in terms of its analytic scope and focus, we would encourage socio-legal researchers to engage with this method for the study of social interaction contributing to the understanding of socio-legal problems.

The data we analyse here are drawn from projects focused on communication and socio-legal issues in dementia care (other findings from which are reported in Harding, 2017; Peel, 2015; Peel and Harding, 2015; 2014; Harding and Peel, 2013). Data include focus group discussions and videorecordings of people living with dementia during their everyday conversations and medical interactions. Although focus group data is researcher-generated rather than completely natural, focus groups are argued to be 'relatively naturalistic' (Wilkinson, 1999) and thus are less artificial than many forms of data gathering (e.g. semi-structured interviews, survey responses). University Ethics Committee approval was granted for the focus group research and, because the videorecording involved NHS patients and participants who may lack capacity to consent, ethical approval was sought from and granted by the Social Care Research Ethics Committee. Pseudonyms have been used throughout the data extracts to protect anonymity, and geographical and occupational details that might identify participants have been changed. Focus groups took place between September and December 2011; everyday and memory clinic appointment recording took place in 2012.

We predominantly draw on examples from naturally occurring talk for two main reasons: first, this allows the researcher to examine how phenomena, in this case power of attorney, are understood endogenously within the local context of use. In other words, rather than defining a priori what power of attorney is (e.g. through legal definitions) and then 'testing' whether lay or professional understandings match this, we take this ordinary discussion as our analytic starting point. Second, analysing naturalistic instances of talk about a subject (rather than decontexualised and secondhand reports in survey responses or interviews) encourages the analysis of the sequential unfolding of the phenomena as interactional, intersubjective and dialogic.

The choice of data excerpts has been necessarily selective in order to have space to explore them in depth. Power of attorney was discussed in all of the focus groups in the project, but we focus here on one fragment from this dataset. In the memory clinic data, out of 18 appointments with 14 patients and accompanying persons, topically relevant talk occurred in seven appointments with five 
Author's Post Print. Accepted for Publication in Socio-Legal Studies on 6 September 2018. Please cite published version where possible.

patients. Our analysis explores two fragments from this wider sub-dataset. Power of attorney talk was less common in everyday life settings, and the fragment we analyse here was the only explicit discussion of it in this dataset. The Jeffersonian transcription notation used (Jefferson, 1984) denotes the spoken features of the talk (e.g. emphasis); see appendix. Whilst this way of presenting interaction may be unfamiliar to the socio-legal reader this level of detail is important "to facilitate the analyst's quest to discover and describe orderly practices of social action in interaction" (Hepburn and Bolden, 2013:58). Alongside our CA approach, we explore the broader discursive meaning making that is present in these data. Discourse analysis assumes that talk and text produces reality rather than reflects it (Wiggins, 2017). In using CA informed discourse analysis, we seek to explore the construction and sequential unfolding of power of attorney talk alongside features of the content of this discourse that assist in uncovering the polyphonic legality of power of attorney.

\section{Dialogic Constructions of Power of Attorney}

We now turn to explore how power of attorney is discussed in two interactional contexts. First, we explore 'lay' interactions about gaining and using power of attorney. We then move on to health care contexts, specifically memory clinic discussions. ${ }^{\text {iv }}$

\section{Lay interaction}

Extract 1 occurs after the researcher (R1) asks focus group members whether they have anything to add about the legal and financial aspects of caring for a person with dementia. This results in three distinct accounts from Morris (line 3-17), Viv (lines 18-44) and James (lines 45-66) about power of attorney.

\section{Extract 1: FG2_D2C}

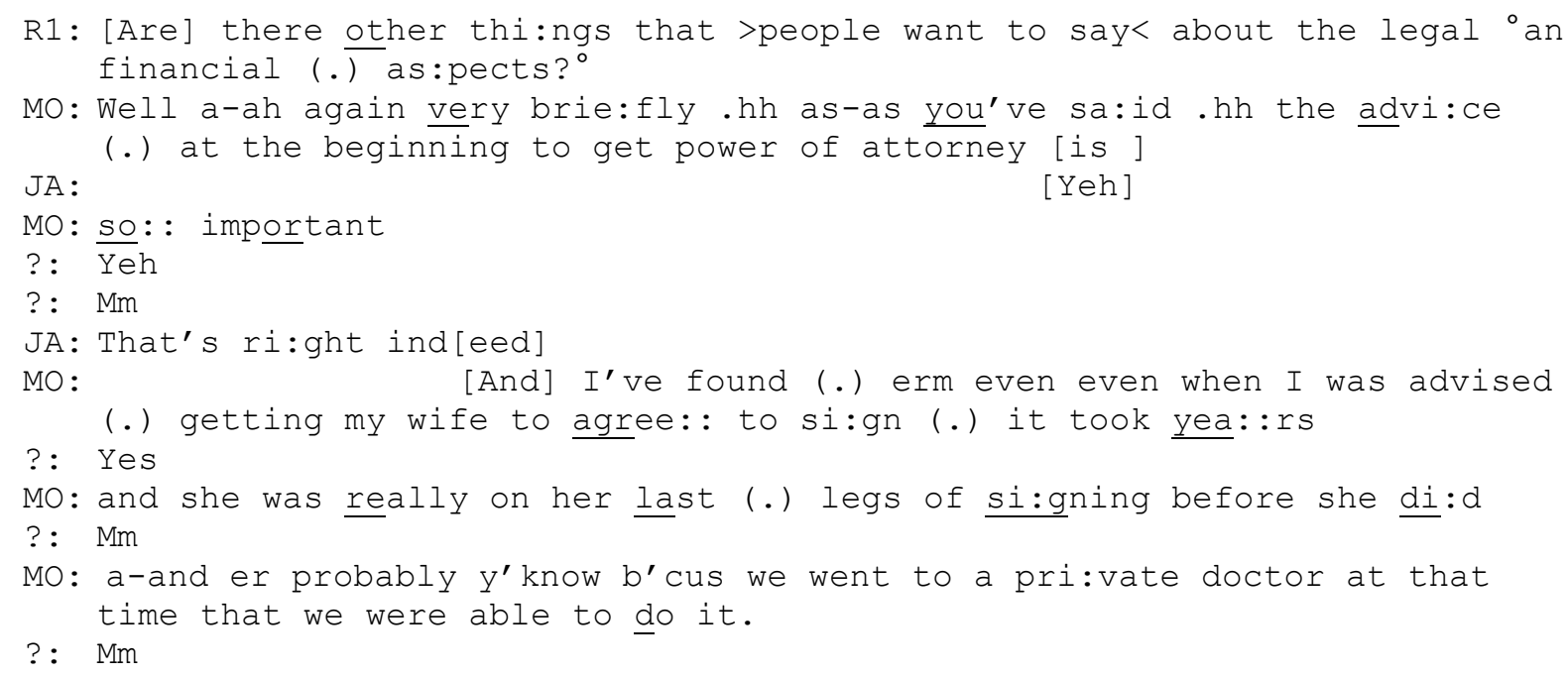


Author's Post Print. Accepted for Publication in Socio-Legal Studies on 6 September 2018. Please cite published version where possible.

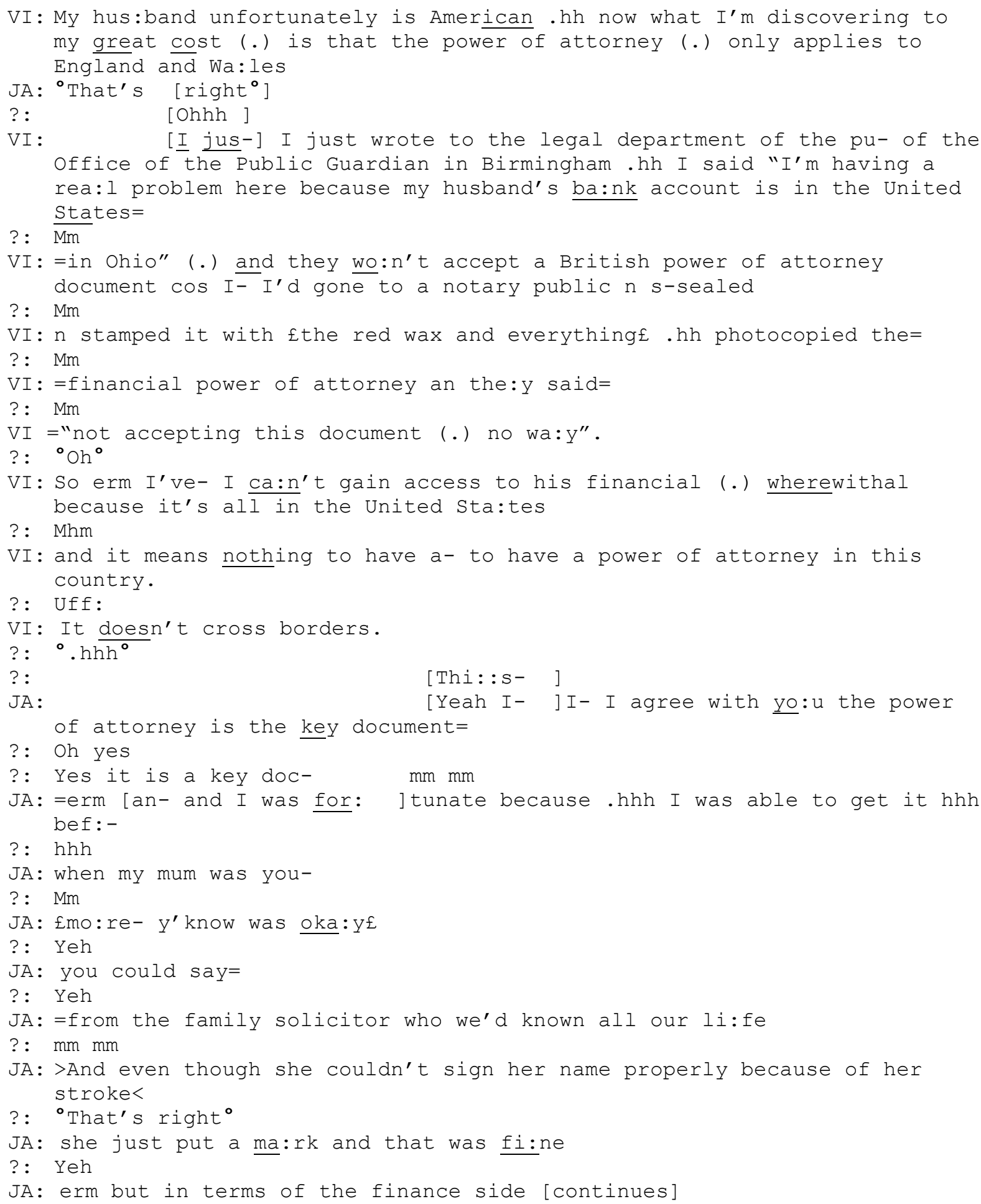

Within this wider discussion these carers and ex-carers have shared unambiguous complaints about the services, and support (or lack thereof) they have received (see further Peel \& Harding, 2014). The first point to note in this extract is the production of the talk about capacity to grant an LPA evident in lines 10-16 and 50-64, in that power of attorney is a delicate and accountable topic wherein stake and personal interest need to be carefully managed (Potter, 1996). Managed, especially pertinently, in the sense of not infringing either the law or the boundaries of capacity. For 
Author's Post Print. Accepted for Publication in Socio-Legal Studies on 6 September 2018. Please cite published version where possible.

instance, Morris (line 10-11) contrasts the importance of timely advice about power of attorney with his wife's reticence to agree, but rather than stopping at characterising his wife's state as 'really on her last legs' (which suggests close to death, and likely not capacitous) he adds 'of signing'. He then completes his turn by alluding to "buying" ('private doctor', line 15) the ability to have the LPA certified. James' 'fortunate' (line 50) may echo Viv's preceding use of 'unfortunately' (line 18) as an opener to her story, but his cut-off at the (likely) word 'before' (line 51) and self-repair and hedging (lines $53,55,57)$ suggests trouble about voicing lack of capacity. His self-repair at 'more' (line 55) to not say more "capable" or "with it" avoids a direct contrast with the implied potential lack of capacity in Morris' account of obtaining an LPA certificate. This illustrates the interactional delicacy needed when discussing the boundaries of capacity when the speaker has a stake in the LPA.

Viv's story (lines 18-43) draws attention to a different dimension of LPAs: the challenge of jurisdictional borders. Here, Viv sets out the difficulties she has experienced using power of attorney in the context of assets held in a different jurisdiction. The performance of official law, and the need to engage with the formalities of legal bureaucracy is highly visible in Viv's account of having the document notarized. Her use of a smiley voice (line 31), denoted with British pound signs, when delivering the phrase 'the red wax and everything' acknowledges laughter and helps to draw attention to the futility of this formal legal performance. She expresses that futility at line 35 through reported speech, a common practice in interaction for both making complaints and for telling amusing stories (Holt, 2000). Here, Viv is both directly complaining about her negative experience of the legalities of power of attorney, and also using prosody (variation in the tone and rhythm of her speech) to add emphasis to her complaint, and to convey her negative view of the constrained legality of power of attorney. Viv's account sits in clear contrast to the other, more positive constructions of the usefulness of power of attorney for carers expressed by other participants in this conversation. Taken together, lay people in this interaction constructed power of attorney as straightforward and geographically bounded, and both a positive and negative tool.

Our second extract arises spontaneously in the context of a day centre meal. We do not know the status of $F$ aside from Derek is making conversation with her via his open question in line 1 and she is seated at the table with him and his wife. She may be a friend, a member of staff, or a volunteer at the day centre.

\section{Extract 2: DT_OH_D\&J}

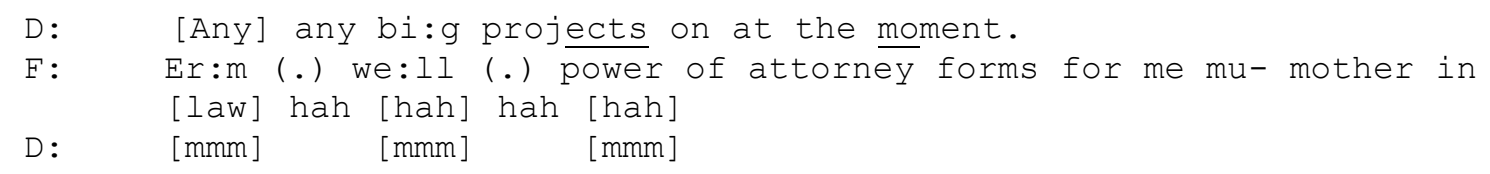


Author's Post Print. Accepted for Publication in Socio-Legal Studies on 6 September 2018. Please cite published version where possible.

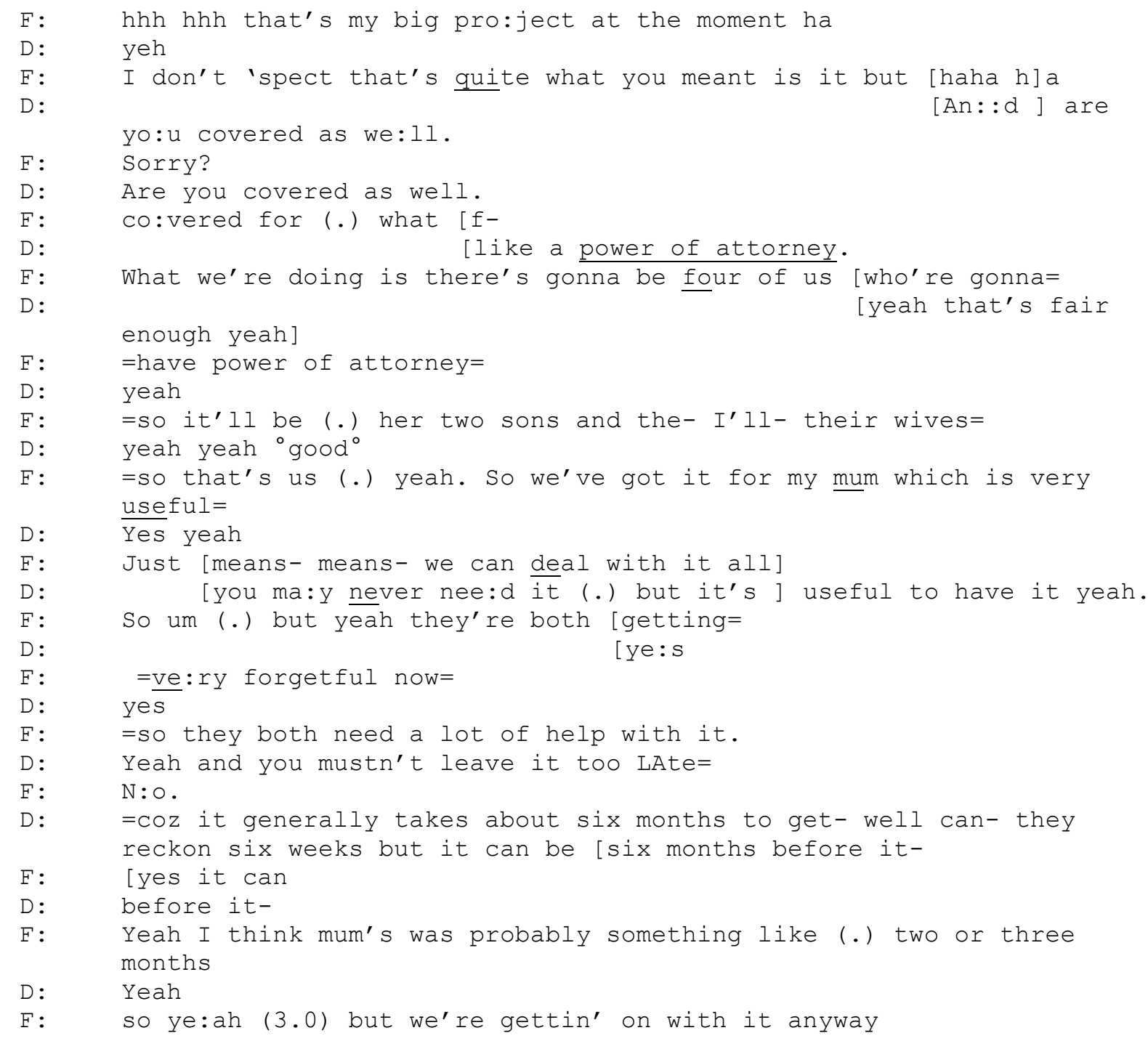

In line 1 Derek is asking - in a non-specific way - about current significant projects. In line $2 \mathrm{~F}$ volunteers the issue of 'power of attorney forms'. She begins her response with "well" which indicates that the answer is not going to be straightforward (Schegloff and Lerner, 2009). There is also a lot of laughter in the delivery of her talk. Laughter can accomplish many different things, in this instance her laughter coupled with 'I don't s'pect that's quite what you meant is it' signals that bringing up power of attorney is both a delicate topic (Haakana, 2008), and one that wouldn't necessarily be anticipated as an "appropriate" response to Derek's question. Derek does not respond in a way that suggests that the topic is inappropriate but rather minimally receipts her turn in lines 4 and 6 and extends the relevant scope of the topic by asking whether she 'will be covered' by the LPA (lines 8-9). Derek's second question is treated as a trouble source by $F$ as she responds with an open class repair initiator (sorry?), which, as Drew (1997) identified, treats the whole of the prior turn as somewhat problematic. In line with what has been identified as a common preference to initially treat an other-initiated repair as a hearing rather than an acceptability or understanding 
Author's Post Print. Accepted for Publication in Socio-Legal Studies on 6 September 2018. Please cite published version where possible.

problem (Svennevig, 2008), Derek's response (line 11) is a straight repetition of his initial question. In line 12 it appears as though $\mathrm{F}$ is going to generate a 'full repeat' of Derek's question, which has been identified as tacitly working to claim that a questioning action is problematic (Robinson and Kevoe-Feldman, 2010) but Derek interrupts with a restatement of his focus on the relevance of power of attorney. $F$ then continues by describing what they are doing regarding power of attorney for her mother-in-law, before going on to describe it as a 'useful' (line 22, repeated by Derek at line 25 ) tool to help families support those who are 'very forgetful' (line 28).

The importance of timeliness in power of attorney, and the challenge of capacity loss arises again in this extract. Here, F refers to the LPA already in place for her mother and its current utility in the, perhaps deliberately vague and non-specific 'we can deal with it all' in overlap with Derek's hypothetical 'you may never need it', referring to the potential uncertainty of future cognitive decline in dementia. This uncertainty around futurity in dementia in the context of LPA is a discursive trope that also appears in the medical interactions we analyse in the next section.

\section{Medical interaction}

The remaining extracts are drawn from routine memory clinic appointments. These extracts highlight different dimensions of the polyphonic legality of power of attorney, as legal, medical and lay understandings are constructed through the dialogue. Extract 3 is reminiscent of some of the ways that LPA is constructed in the lay interaction above, and is an example of a psychiatrist seeking to persuade the patient and her son to seek legal advice about LPA, as a preferable alternative to a deputyship appointment.

\section{Extract 3-MC2: Irene, Pete and Psychiatrist}

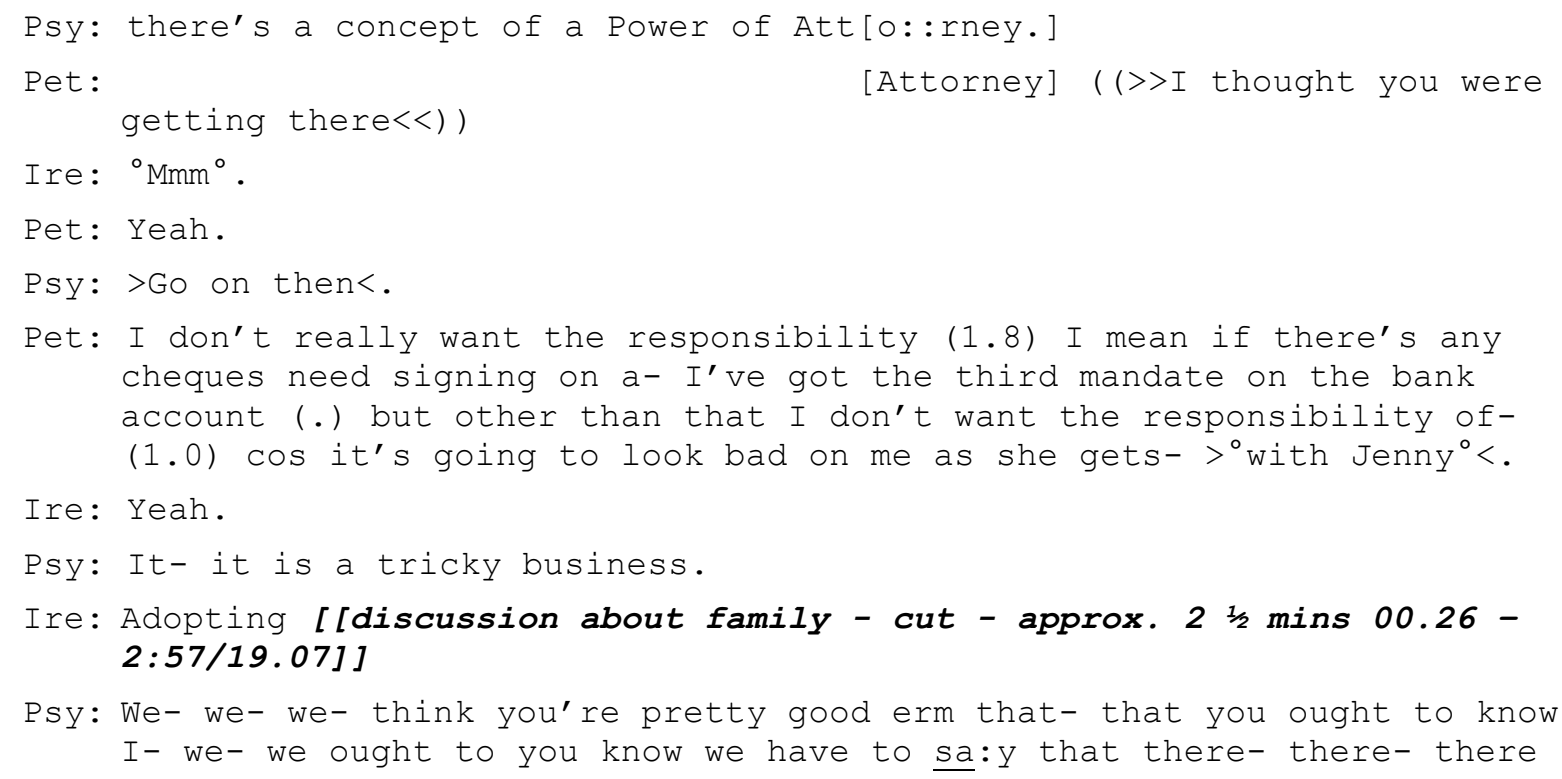


Author's Post Print. Accepted for Publication in Socio-Legal Studies on 6 September 2018. Please cite published version where possible.

is a device where you can- you can make arrangements that if there ca:me a time where you- you couldn't be organising your finances

[and so on

Ire: [And look after ya.

Psy: that you can through the solicitor do what's called a- a power of attorney in- in anticipation it-it's called a Lasting power of attorney .

Pet: Mm.

Psy: So that- at the moment you're fully compos you can do everything but if a time came (.) that you cou:ldn't do it (.) what would happen (1.0) the legal requirement would be that somebody is named to take over on your behalf.

Ire: Ah yeah, yeah.

Psy: The- the legislation allows you to choose or to- to- to arrange it. It can be that it's a joint power

Ire: $\mathrm{Mm}$.

Pet: $\mathrm{Mm}$.

Psy: between, for instance, yourself and Jenny d'you know so that- because as you say if it-if it goes to one and not the other

Ire: Yeh.

Psy: people can be jealous and suspicious=

Pet: ( )

Psy: =and all that sort of business. But if you've got a family solicitor who can look at things carefully with all of you- it may well be worth it it may well be worth it.

Ire: $\mathrm{Mm}$.

Psy: Cos you can't be sure- it may never be necessary- but it's just- just

Pet: A thought (.) yeah.

Ire: A thought (.) ye:s.

Psy: Cos I think this is it-isn't it- and people are a bit anxious that here you are still running- running the show but you're saying "well I put it in the wrong column and I hadn't noticed and it's not my eyesight" it's just- just how it is. I'm going- is it all right- I'm going to test your memory 
Author's Post Print. Accepted for Publication in Socio-Legal Studies on 6 September 2018. Please cite published version where possible.

Looking closely at this interaction, we see Pete cuts off at 'a-' (line 8) before the projectable phrase 'regular basis' and then self-repairs to the phrase 'I've got the third mandate on the bank account' expressing his desire to limit his involvement to signing cheques, in case it 'looks bad' in the eyes of his sister (Jenny). The psychiatrist receipts this information with 'it is a tricky business' (line 12), which then sparks a lengthy discussion of family history. The psychiatrist eventually steers the conversation back to the issue of LPA. There is a local temporality in this, he has not yet conducted any cognitive testing, but has made a global assessment in line 15 based on the history taking that 'we think you're pretty good'. When mentioning LPA the psychiatrist initially grounds this is as a potentially unlikely future necessity in lines 17-18 ('if there came a time where') and line 26 ('if a time came') contrasting with, what he produces as his own putative "duty" to mention the 'device' (LPA) in lines 15-16 ('you ought to know'; 'we have to say').

That the psychiatrist is persuading Irene as to the value of considering an LPA is borne out as the sequence unfolds. There is something of a reaction token (Wilkinson \& Kitzinger, 2006) from Irene (line 29, 'ah') and agreement and alignment in the form of 'yeah, yeah', rather than the more usual minimal receipt (a ' $\mathrm{mmm}$ ' continuer) common in asymmetric medical interaction (Pilnick \& Dingwall, 2011). Further evidence of "buy-in" from the patient and her (initially resistant) son comes at Pete's completion of the psychiatrist's turn in line 44 and Irene's full repeat of this in line 45 . Before moving the interaction onto the next activity - the cognitive assessment - the psychiatrist adeptly affirms the importance of thinking about LPA (line 46 'cos I think this is it- isn't it'). The psychiatrist uses active voicing (i.e. reported speech) from the patient herself (lines 47-49) as a collaborative turn structure which co-implicates the patient (Ekberg and LeCouteur, 2014) into his stance that 'it may well be worth' (line 41) organising LPA. In closing the discussion, the psychiatrist also uses axiomatic and idiomatic language (e.g. 'just how it is', 'running the show') which is robust and hard to deny (Hepburn and Potter, 2011), alongside the vague generality of 'people' (line 46) being 'a bit anxious' about her cognitive functioning, to which the conversational topic is then shifted.

Looking to the content, rather than construction, of this talk brings us to a second interesting discourse in this extract: the mention by the psychiatrist that 'if it goes to one and not the other, people can be jealous and suspicious' (lines 35-37). This putative reason for granting power of attorney echoes the familial, relational negotiation evident in the lay interactions. Moreover, within this interaction the psychiatrist's move from a singular 'somebody' (line 27) being 
Author's Post Print. Accepted for Publication in Socio-Legal Studies on 6 September 2018. Please cite published version where possible.

'named' (which he implies would happen through a deputy appointment process) to the more specific and relationally nuanced 'yourself and Jenny' (line 34) that can be appointed through an LPA, operates as a more persuasive recipient design (namely tailoring the message for the specific recipient), in that this reformulation personalises the process (Hepburn and Potter, 2011). This links back to Pete's initial concern and reticence to have the 'responsibility' because 'it's going to look bad on me' (line 10). This linkage is done explicitly through the phrase 'as you say' (line 35) but 'people can be jealous and suspicious' (lines 37) is a significant upgrade and more emotive way of expressing these issues. Whereas the (implicit) talk about the need to appoint a deputy suggests that only one of Irene's children could be appointed, the flexibility of LPA allows both to be equally involved, in a way that perhaps more appropriately reflects the complexities of kinship (Riggs and Peel, 2016).

Our second memory clinic interaction (Extract 4) is a conversation between a person with dementia (Emily) and the psychiatrist about the certification of capacity provider rules under the MCA.

\section{Extract 4: MC2 Emily (home visit)}

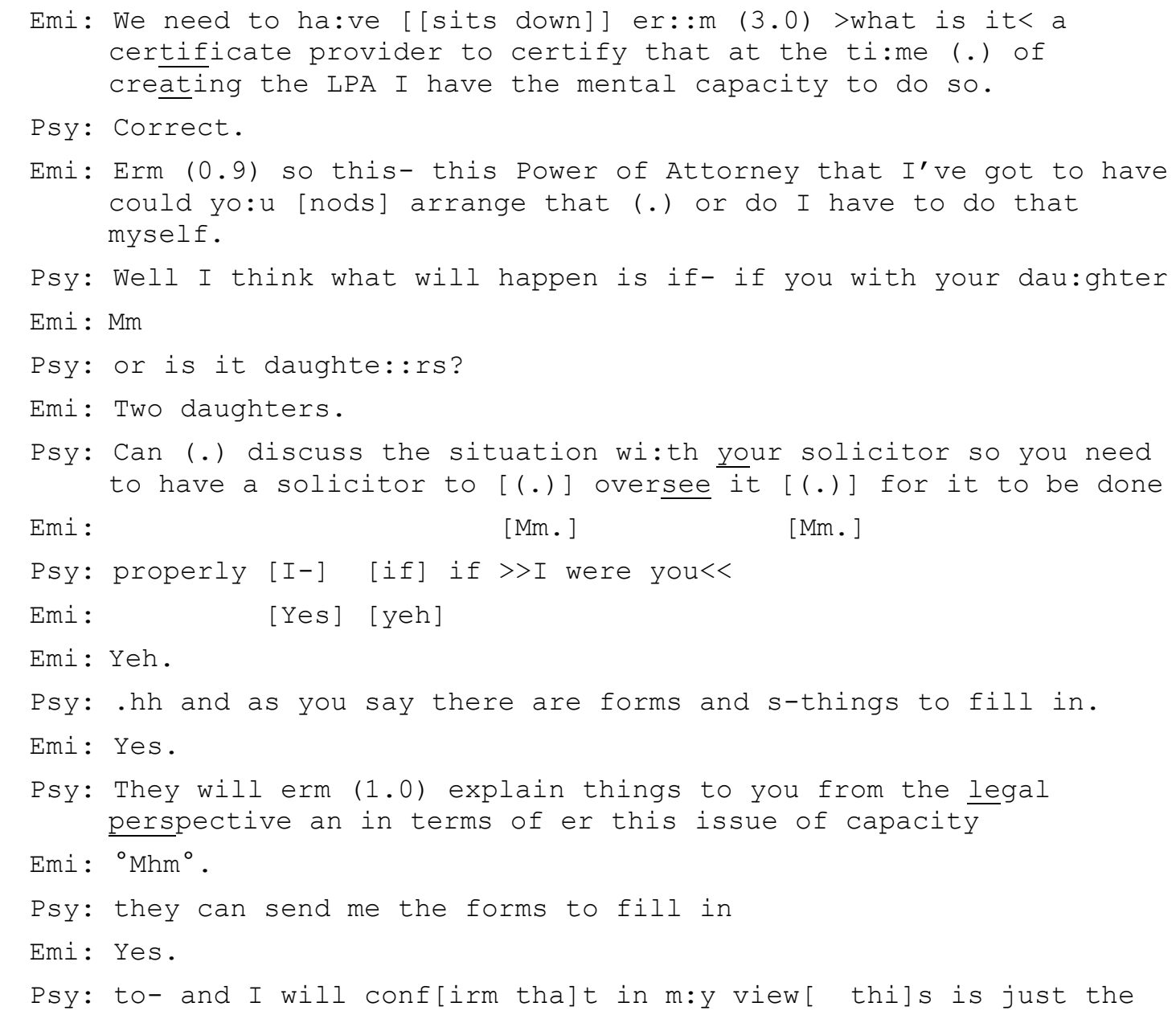


Author's Post Print. Accepted for Publication in Socio-Legal Studies on 6 September 2018. Please cite published version where possible.

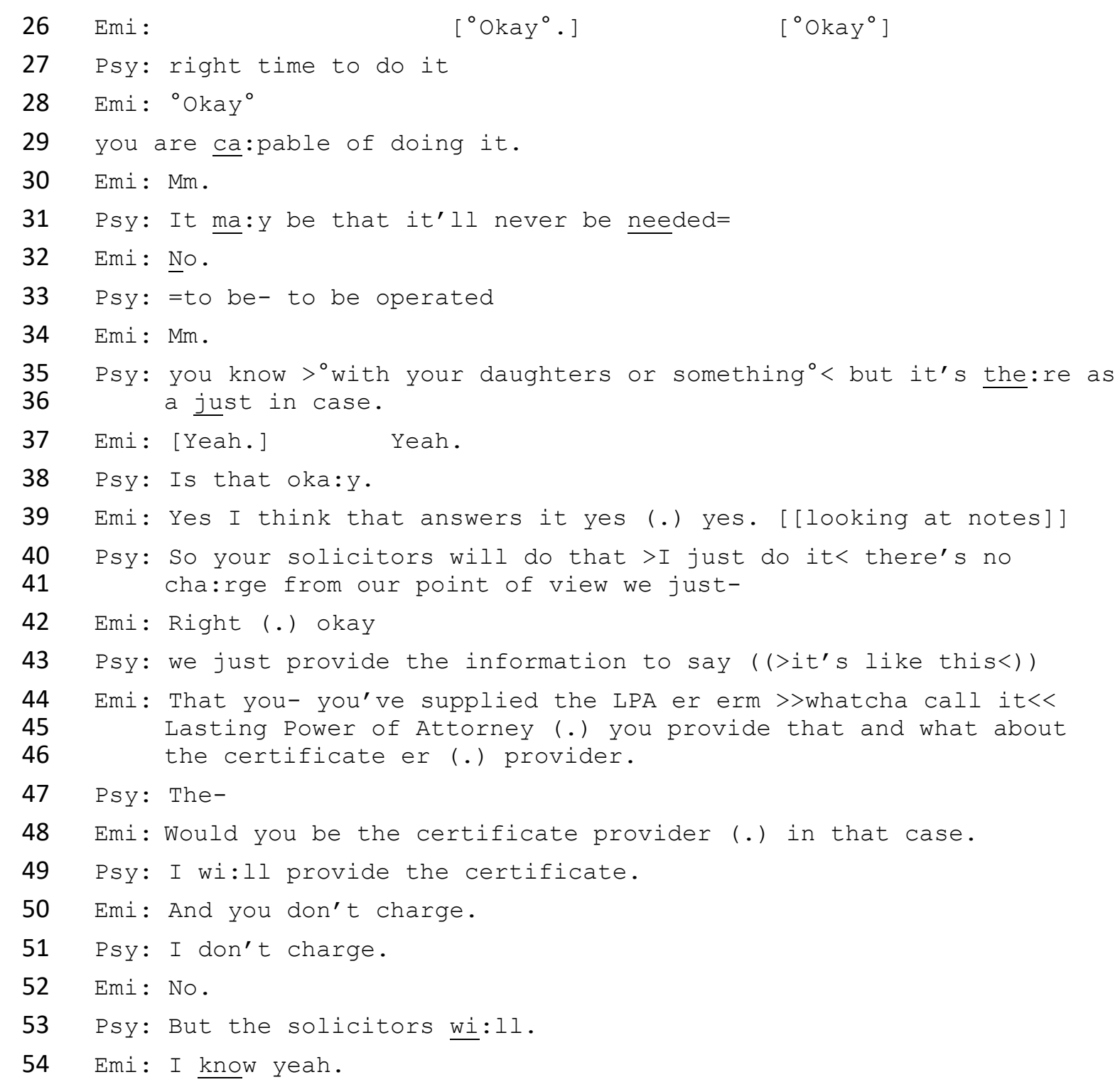


Author's Post Print. Accepted for Publication in Socio-Legal Studies on 6 September 2018. Please cite published version where possible.

At the beginning of the interaction (lines 1-3) Emily is reading from a note, which contains the phrase 'certificate provider' as a person who can certify that at the time of creating the LPA she has the appropriate capacity.

The psychiatrist begins his turn in this interaction with a generic introduction to the process of getting an LPA, prefacing his account with 'well' (Schegloff and Lerner, 2009), again projecting that his response to the question will not be straightforward. This psychiatrist firmly places the formalities of LPA 'there are forms and things to fill in' within the professional domain of a solicitor 'you need to have a solicitor to oversee it for it to be done properly' (lines 12-15). He then gets on to the issue of the certificate provider, but without signalling explicitly in his talk that he has done so (lines 20-25). Instead, he says that he 'will confirm' that in his view it is 'just the right time to do it'. He also affirms his view that Emily has the capacity to grant LPA (line 29) 'you are capable of doing it'. Throughout this interaction, we see the psychiatrist claiming 'expert' knowledge of capacity, in the context of being the 'certificate provider' for her LPA application, whilst describing solicitors as experts in the legal formalities of LPA. We again have reference to the possibility that the LPA may never be needed, which reflects lay discourse (extract 2 ), and the previous medical interaction (extract 3).

In one sense, this is an ideal interaction. Emily is in the early stages of dementia and gets advice from her psychiatrist to look into power of attorney. She takes action on the basis of his advice, discovers she requires certification of her capacity, asks her psychiatrist to provide this, and he confirms she has capacity and will provide the certificate. Yet there are two interesting discursive manoeuvres in this conversation. There is a remarkable juxtaposition of the different professional arenas of law and medicine. This comes through particularly in the way that the psychiatrist constructs the different roles of the solicitor (line 20-21) and himself (line 21-29). Here, law is relegated to formalities, whereas 'capacity' is claimed as psychiatric knowledge. Another interesting juxtaposition is between the different cost implications between legal and medical knowledge - under the UK National Health Service, his role in the process is free, 'I don't charge' (line 51) in contrast to the solicitors 'but the solicitors will' (line 53), with the elongation of the word 'will' placing emphasis and constructing contrast between the free medical service, and the costly legal service.

The way the talk unfolds around the more explicit discussion of the certificate provider is also remarkable. At line 48, Emily expresses her moment of realisation both verbally and non-verbally as she asks if the psychiatrist would be the certificate provider (using the legal terminology). In response, the psychiatrist uses an unusually definitive phrasing - ‘l wi:ll provide the certificate’ (line 49). We can understand this as both providing an affirmative response to Emily's question, and 
Author's Post Print. Accepted for Publication in Socio-Legal Studies on 6 September 2018. Please cite published version where possible.

reinforcing the claim that the certification of capacity is a psychiatric task, requiring medical professional skill. This location of capacity as psychiatric knowledge is in direct contrast to the formalities of the MCA. It would be considered a matter of good practice to gain a professional (rather than lay) assessment of capacity if there is the chance that the donor's capacity will be questioned, but this is not formally required by the MCA or the LPA regulations which also allow lay certification. ${ }^{\vee}$ Examples in the regulations of persons with appropriate professional skill to provide a professional certificate include registered health care providers, legal professionals, social workers and Independent Mental Capacity Advocates. ${ }^{\text {vi }}$ Extract 4 therefore reflects a medicalisation of the LPA certificate provider rules in the context of dementia.

In this section, we have analysed four extracts from dialogue about power of attorney. Through this talk, we have highlighted the multiple ways power of attorney is constructed through lay and medical discourse. Power of attorney is legally understood in individualistic terms, grounded in the common law of agency. The legal purpose of power of attorney is to allow a donee to make decisions that are as legally valid and binding as if they were made by the donor. At common law, power of attorney, as an agency relationship, automatically became invalid if the donor lost the capacity to make their own decisions (Watts and Reynolds, 2014). The purpose of a lasting power of attorney, therefore, is to facilitate the continued legal authority of the (individual) donor, through a substitute decision-maker, after they have lost the functional ability to make their own decisions.

The doctrinal legal construction of power of attorney is as a straightforward individual agency relationship, governed by detailed formal regulatory frameworks (Rich, 2015; Samanta, 2009). In contrast, by exploring the multiple voices and constructions present in lay and medical accounts of gaining power of attorney in the context of dementia, our polyphonic approach has exposed the LPA as relational, bounded, and contingent. In demonstrating the relational nature of power of attorney, we exposed how carers and people with dementia talked about the need to negotiate the complexities of kinship and relationships in the process of granting, gaining and using an LPA. We further exposed how the doctrinal power of law expressed in LPAs are constrained by jurisdictional boundaries despite the ubiquity of agency relationships within the common law world. The complexities of international recognition of LPA raised in our first excerpt stands in stark contrast to both a blackletter construction of the official nature of the power of attorney documentation, and to the construction of LPA as a formal document, requiring professional attention to ensure compliance with legal formalities (Edwards, 2016). This polyphonic approach has therefore exposed the LPA as geographically bounded, constrained, and unenforceable. Finally, our lay and medical interactions exposed the contingency of LPA through the repeated use of discursive formulations of a generically 
Author's Post Print. Accepted for Publication in Socio-Legal Studies on 6 September 2018. Please cite published version where possible.

uncertain future necessity. This uncertainty was often, however, contrasted with personal accounts of current utility, and the expressed or implied likelihood of an impending decline in capacity. In summary, the multiple voices that have emerged through our polyphonic approach have exposed the richly textured legality of power of attorney in everyday life.

\section{Reading Polyphonic Legality}

Lay and medical constructions work with legal understandings to create the polyphonic legality of power of attorney. In this final section, we discuss the implications of understanding power of attorney as holding a polyphonic legality. We have shown through our analysis that the legality of power of attorney is not only that which is written in the relevant statutes and interpreted by the courts. Instead, power of attorney is woven together by the complex interplay of the different voices present in law, medicine, and everyday interaction.

The interactions we have reproduced here are not intended to represent the entirety of the polyphonic legality of power of attorney. Rather, we consider that further strands of polyphony are added as attorneys use the powers granted by the LPA, in everyday contexts, commercial transactions and in health and social care settings. There are other layers of polyphony in power of attorney that we have not charted here: in decisions about residence, or about social and personal care, there may also be voices from social workers, best interests assessors, or care providers. When LPAs are used to engage in financial transactions, the ways that bank tellers, call centre workers or online systems respond may add another strand to the polyphony. The actors involved in power of attorney discussions and practice will also have differential experiences according to social indicators like social class, gender, race/ethnicity, education level and economic position. Some voices may carry more weight than others, for example, as foregrounded in these data when Morris alludes to 'buying' certification from a 'private doctor'. We argue that these strands each offer something different, important and internal to the polyphonic legality of power of attorney, whilst also working together to create a fuller interpretation it as a socio-legal concept. Each discursive realm has its own dialogic timbre, which, when brought together with the others, combine to create the polyphonic whole. Rather than the formal legal strand of this polyphony providing the melodic line, we argue that it is within the polyphonic whole that the entire complex, contingent, and relational legality of power of attorney can be found.

In developing this idea of polyphonic legality, we hoped to expose how legal instruments, like power of attorney, are necessarily shaped by their everyday usage, and dialogically constructed not only in the privileged arenas of law, but also through everyday interaction. We argue that analysis of this 
Author's Post Print. Accepted for Publication in Socio-Legal Studies on 6 September 2018. Please cite published version where possible.

dialogic construction, which exposes the ways that social interaction constructs, as well as reflects, legality offers a new conceptual tool for socio-legal studies.

Some might argue that to construct a legal concept in this way would be too great a stretch from the formal domain of law, perhaps suggesting that official law should be understood differently from, or given more prominence than the other voices present. Certainly, there are some formalities that must be adhered to for an LPA to be registered by the Office of the Public Guardian (OPG). If an LPA does not conform to those legal formalities set out in the MCA then it is possible that it may not be registered by the OPG. Yet in The Public Guardian's Severance Applications, a recent English Court of Protection case concerning the formalities of registration of 17 electronically completed LPA forms, vii Eldergill DJ described the MCA as an 'enabling Act', which requires the Court and the Public Guardian to 'be as enabling as is legally possible'. viii

The enabling approach taken by the Court of Protection included ignoring formalistic errors like the donor having ticked the wrong box on the form, or technical irregularities in the positioning of witness names and addresses. Other examples in that case included where the donor had asked that their attorneys consider the needs of a third party (a disabled son and a donor's mother and daughter) when discharging their duties, thus recognising the relational nature of individual decision-making. These may appear to be minor irregularities, but refusing registration of an LPA on the basis of them, as a formalist doctrinal interpretation would require, would have profound effects on the donor, especially if they lacked capacity to correct the error. In the case of property and affairs LPAs, the consequence may be that a deputy appointment is required, with all of the attendant additional costs. In the case of a health and welfare LPA, given the relatively rare appointment of welfare deputies, refusal of registration may operate to overrule the donor's wishes about future health and care decision-making.

Power of attorney provides a particularly pertinent example for demonstrating the difference that a polyphonic legality approach provides. This is because it is a commonplace legal instrument, which has its foundations in the common law of agency but is most often mobilised in the relationally focused realm of social welfare and family law. Power of attorney is a legal tool which operates on multiple levels, providing documentary evidence of authority to act on behalf of another in a wide range of contexts. As a result, power of attorney appears in social interaction in more domains than many other legal concepts, adding more voices to its polyphonic legality. These multiple domains and voices allow us to explore how the dialogic construction of power of attorney contributes to socio-legal meaning-making in a range of settings. Unlike other constitutive approaches to law and society, our use of polyphonic legality does not seek to interrogate and understand the enduring 
Author's Post Print. Accepted for Publication in Socio-Legal Studies on 6 September 2018. Please cite published version where possible.

power of formal law. Instead, in using this concept, we offer an alternative way of exploring how law works in everyday life, one which seeks to be attentive to the multiple, dialogic and discursive constructions of legal concepts that combine to create a polyphonic legality.

\section{Concluding Remarks}

The polyphonic legality of capacity law may explain why efforts to change the regulatory framework in the messy everyday world of social welfare and family law often require much more than legislative reform. The complexity and depth provided by analysis of polyphonic legality can help to shows us why the MCA, for example, which is widely considered to be 'good law', has been so difficult to implement (House of Lords, 2014). If we change the legislative framework involved in a polyphonic legality, we only change one of many voices. The other voices (lay people, healthcare professionals, social workers etc) will interpret and deploy those laws in conflicting ways, orderly within their local dialogic context yet only partially aligned with the doctrinal voice. By changing formal law, we will certainly change something, but we will not always succeed in changing the whole polyphonic legality.

Polyphonic legality, in our view, is not only applicable in the complex realm of capacity law. Here we have used conversation analytically informed discourse analysis to map out its operation in power of attorney. Perhaps it is easier to isolate the different voices in relatively subjective areas like social welfare and family law, than it might be in other, more heavily doctrinal, areas of legal knowledge. Yet in all areas of law, legal rules are used and interpreted by different actors, to shape, shift and create the totality of the regulatory framework. Importantly, power of attorney is a common law concept, with its roots in the law of agency. It has been solidified into the novel terrain of mental capacity through legislative change. This model is one which is replicated across many areas of law. The idea of polyphonic legality could be used by empirical legal scholars to investigate how other legal concepts, rules and ideas are used in practice through similar dialogic analysis to that which we set out here. Such analysis could, for example, explore how complex regulatory systems work in the contexts of environmental, planning, or health and safety law as implemented in practice. Indeed, we consider that polyphonic legality offers a novel approach to understanding the gap between the law as it is written and as it is experienced in any area of law which relies on commercial, professional or personal implementation and engagement.

\section{Acknowledgements}

The ideas in this paper benefited from presentation and discussion at the SLSA Annual Conference 2017, seminars at Lund University, Sweden, Birmingham Law School, and a DARG - Discourse and Rhetoric Group - data session at Loughborough University. The authors would like to thank Charles 
Author's Post Print. Accepted for Publication in Socio-Legal Studies on 6 September 2018. Please cite published version where possible.

Antaki, Marco Pino, Ellen Gordon-Bouvier, Jaime Lindsey, Jean McHale, Ben Warwick and the two anonymous reviewers for their thoughtful provocations.

\section{Funding}

This work was supported by the British Academy grant numbers SG1000017, MCF110142 and MD150026.

\section{References}

Antaki C (2011) Six kinds of applied conversation analysis. In C Antaki (ed) Applied Conversation Analysis: Intervention and change in institutional talk. (pp. 1-14). London: Palgrave Macmillan.

Bakhtin MM (1984) Problems of Dostoevsky's Poetics Minneapolis, MA: University of Minnesota Press.

Conley, J and O'Barr, W (1990) Rules versus Relationships: The Ethnography of Legal Discourse, Chicago: University of Chicago Press.

Cowan D (2004) Legal Consciousness: Some observations. Modern Law Review, 67(6):928-958.

Dalley G, Gilhooly M, Gilhooly K, Levi M, and Harris P (2017) Exploring financial abuse as a feature of family life: an analysis of Court of Protection cases. Elder Law Journal, 7(1): 28-37.

Davies M (2017) Law Unlimited: Materialism, Pluralism and Legal Theory Abingdon: Routledge.

Drew P (1997) 'Open' class repair initiators in response to sequential sources of troubles in conversation. Journal of Pragmatics, 28(1): 69-101.

Durkheim E (1982) The Rules of Sociological Method ed. S Lukes. Trans WD Halls. New York: The Free Press

Edwards S (2016) Law and practice relating to property and affairs deputies: Problems encountered and how to deal with them. Elder Law Journal 6(4): 365-373.

Ehrlich E (1936/2002) Fundamental principles of the sociology of law. Trans. WL Moll. New Brunswick, NJ: Transaction Publishers.

Ekberg K and LeCouteur A (2014) Co-implicating and re-shaping clients' suggestions for behavioural change in cognitive behavioural therapy practice. Qualitative Research in Psychology, 11(1): 60-77. 
Author's Post Print. Accepted for Publication in Socio-Legal Studies on 6 September 2018. Please cite published version where possible.

Ewick P and Silbey SS (1998) The Common Place of Law: Stories from everyday life. Chicago and London: Chicago University Press.

Fleurry-Steiner B and Nielsen LB (eds) (2006) The New Civil Rights Research: A Constitutive Approach. Aldershot: Ashgate.

Garfinkel H (1967) Studies in Ethnomethodology. Englewood Cliffs, NJ: Prentice Hall.

Haakana M (2008) Laughter as a patient's resource: Dealing with delicate aspects of medical interaction. Text, 21(1-2): 187-219.

Harding R (2011) Regulating Sexuality: Legal Consciousness in Lesbian and Gay Lives Abingdon: Routledge.

Harding R (2015) Statutory Wills and the Limits of Best Interests Decision-Making. Modern Law Review 78(6): 945-970.

Harding R (2017) Duties to Care: Dementia, Relationality and Law. Cambridge: Cambridge University Press.

Harding R and Peel E (2013) "He was like a zombie": Off-label prescription of antipsychotic drugs in dementia. Medical Law Review, 21: 243-277.

Hepburn A and Bolden GB (2013) The conversation analytic approach to transcription. In J Sidnell and T Stivers (eds) The Handbook of Conversation Analysis. (pp. 57-76) London: Blackwell.

Hepburn A and Potter J (2011) Designing the recipient: Managing advice resistance in institutional settings. Social Psychology Quarterly, 74(2): 216-241.

Hertogh M (ed) (2009) Living Law: Reconsidering Eugen Ehrlich. Oxford: Hart.

Holt, E (2000) Reporting and Reacting: Concurrent Responses to Reported Speech. Research on Language and Social Interaction 33(4): 425-454.

House of Lords (2014) Mental Capacity Act 2005: Post-legislative Scrutiny. HL Paper 139 Available at: https://publications.parliament.uk/pa/ld201314/Idselect//dmentalcap/139/139.pdf last accessed 16 January 2018.

Jefferson G (1984) Transcription notation, in J Atkinson and J Heritage (eds), Structures of Social Interaction, New York: Cambridge University Press. 
Author's Post Print. Accepted for Publication in Socio-Legal Studies on 6 September 2018. Please cite published version where possible.

Kitzinger C (2000) Doing feminist conversation analysis. Feminism \& Psychology 10(2): 163-193.

McCann M (1994) Rights at Work: Pay Equity Reform and the Politics of Legal Mobilization. Chicago: University of Chicago Press.

Merry SE (1988) 'Legal Pluralism', Law \& Society Review, 22(5): 869-896.

Merry, SE (1990) Getting Justice and Getting Even. Chicago: University of Chicago Press.

Nelken D (2008) Eugen Ehrlich, living law, and plural legalities. Theoretical Inquiries in Law 9(2): 443471.

Office of the Public Guardian (2017) Annual Report and Accounts 2016/17 HC 180 Available at: https://www.gov.uk/government/collections/opg-annual-reports last accessed 5 July 2018.

Peel E (2015) Diagnostic communication in the memory clinic: A conversation analytic perspective. Aging \& Mental Health, 19(12): 1123-1130.

Peel E and Harding R (2014) "It's a huge maze, the system, it's a terrible maze": Dementia carers' constructions of navigating health and social care services. Dementia. 13(5):642-661.

Peel E and Harding R (2015) A right to 'dying well' with dementia? Capacity, 'choice' and relationality. Feminism \& Psychology 25(1): 137-142.

Pilnick A and Dingwall R (2011) On the remarkable persistence of asymmetry in doctor/patient interaction: A critical review. Social Science \& Medicine, 72: 1374-1382.

Potter J (1996) Representing Reality. London: Sage.

Rich B (2015) Property problems for property and affairs attorneys and deputies. Elder Law Journal 5(4): 383-391.

Riggs DW and Peel E (2016) Critical Kinship Studies. London: Palgrave Macmillan.

Robinson JD and Kevoe-Feldman H (2010) Using full repeats to initiate repair questions. Research on Language and Social Interaction, 43: 232-259.

Samanta J (2009) Lasting powers of attorney for healthcare under the Mental Capacity Act 2005: enhanced prospective self-determination for future incapacity or a simulacrum? Medical Law Review 17: 377-409. 
Author's Post Print. Accepted for Publication in Socio-Legal Studies on 6 September 2018. Please cite published version where possible.

Samanta J (2012) There's nothing new in dying now: Will welfare attorney decision-making at end of life make a real difference? Journal of Law \& Society 39(2): 241-268.

Sarat A (1990) ...The Law Is All Over: Power, resistance and the legal consciousness of the welfare poor. Yale Journal of Law and the Humanities. 2: 343-379.

Schegloff EA and Lerner GH (2009) Beginning to Respond: Well-prefaced responses to wh-questions. Research on Language \& Social Interaction 42(2): 91-115.

Sidnell J (2010) Conversation Analysis. Chichester: Wiley-Blackwell.

Silbey SS (2005) After Legal Consciousness. Annual Review of Law and Social Science. 1: 323-368.

Stokoe E (2011) Simulated interaction and communication skills training: The 'Conversation-Analytic Role-Play Method'. In C Antaki (ed) Applied Conversation Analysis. (pp. 119-139) London: Palgrave Macmillan.

Svennevig J (2008) Trying the easiest solution first in other-initiation of repair. Journal of Pragmatics, 40(2): 333-348.

Travers M (1997) The Reality of Law: Work and Talk in a Firm of Criminal Lawyers Aldershot:

Dartmouth.

Travers M \& Manzo JF (1997) (eds) Law in Action: Ethnomethodological and conversation analytic approaches to law. Farnham: Ashgate.

Watts P and Reynolds FMB (2014) Bowstead and Reynolds on Agency $20^{\text {th }}$ Edition, London: Sweet \& Maxwell.

Wiggins S (2017) Discursive Psychology. London: Sage.

Wilkinson S (1999) Focus groups: A feminist methodology. Psychology of Women Quarterly 23(2): 221-244.

Wilkinson S and Kitzinger C (2006) Surprise as an interactional achievement: Reaction tokens in conversation. Social Psychology Quarterly, 69(2): 150-182.

\section{Appendix: Transcription Notation}


Author's Post Print. Accepted for Publication in Socio-Legal Studies on 6 September 2018. Please cite published version where possible.

\begin{tabular}{lll} 
Symbol & Name & Use \\
\hline [ text ] & Brackets & Indicates the start and end points of overlapping speech. \\
$=$ & Equal Sign & $\begin{array}{l}\text { Indicates the break and subsequent continuation of a single } \\
\text { interrupted utterance. }\end{array}$
\end{tabular}

\begin{tabular}{ll}
\hline (\# of seconds) Timed Pause & $\begin{array}{l}\text { A number in parentheses indicates the time, in seconds, of a } \\
\text { pause in speech. }\end{array}$
\end{tabular}

\begin{tabular}{lll}
\hline (.) & Micropause & A brief pause, usually less than 0.2 seconds. \\
\hline or $\downarrow$ & $\begin{array}{l}\text { Period or Down } \\
\text { Arrow }\end{array}$ & Indicates falling pitch. \\
&
\end{tabular}

? or $\uparrow \quad$ Question Mark or $\quad$ Indicates rising pitch.
Up Arrow

\begin{tabular}{|c|c|c|}
\hline ' & Comma & Indicates a temporary rise or fall in intonation. \\
\hline- & Hyphen & Indicates an abrupt halt or interruption in utterance. \\
\hline$>$ text $<$ & $\begin{array}{l}\text { Greater than / Less } \\
\text { than symbols }\end{array}$ & $\begin{array}{l}\text { Indicates that the enclosed speech was delivered more } \\
\text { rapidly than usual for the speaker. }\end{array}$ \\
\hline$<$ text $>$ & $\begin{array}{l}\text { Less than / Greater } \\
\text { than symbols }\end{array}$ & $\begin{array}{l}\text { Indicates that the enclosed speech was delivered more } \\
\text { slowly than usual for the speaker. }\end{array}$ \\
\hline$\circ$ & Degree symbol & Indicates whisper or reduced volume speech. \\
\hline ALL CAPS & Capitalized text & Indicates shouted or increased volume speech. \\
\hline underline & Underlined text & Indicates the speaker is emphasizing or stressing the speech. \\
\hline$:::$ & Colon(s) & Indicates prolongation of an utterance. \\
\hline (hhh) & & Audible exhalation \\
\hline ? or (.hhh) & High Dot & Audible inhalation \\
\hline ( text ) & Parentheses & Speech which is unclear or in doubt in the transcript. \\
\hline$(($ italic text $))$ & $\begin{array}{l}\text { Double } \\
\text { Parentheses }\end{array}$ & Annotation of non-verbal activity. \\
\hline
\end{tabular}


Author's Post Print. Accepted for Publication in Socio-Legal Studies on 6 September 2018. Please cite published version where possible.

\footnotetext{
'MCA, s. 9

ii Kleinwort Benson v Lincoln City Council [1999] 2 AC 349 at 358, (per Lord Browne-Wilkinson.)

iii Though see Conley \& O’Barr (1990) and Travers \& Manzo (1997) for notable examples.

iv This clinic was a 'one-stop' service. Power of attorney talk may not be so regularly found in other health services.

${ }^{v}$ MCA, sched 1, para 8.

vi Lasting Powers of Attorney, Enduring Powers of Attorney and Public Guardian Regulations 2007 SI 2007/1253 paragraph 8.

vii The Public Guardian's Severance Applications [2017] EWCOP 10

viii Ibid, at [41]
} 